\title{
Differences in The Number of Germs in The Insertion Area of Central Venous Catheter (CVC) Done by Polyurethane Transparent and Plaster Gauze Dressing
}

\author{
Septiana Fathonah ${ }^{1}$, Tri Wahyu Murni ${ }^{2}$, Etika Emaliyawati ${ }^{3}$ \\ ${ }^{1}$ Notokusumo Nursing Academy, ${ }^{2}$ Hasan Sadikin Hospital, ${ }^{3}$ Faculty of Nursing, Universitas Padjajaran \\ Email:ninazahro@yahoo.com
}

Submitted: 17-06-2017 Accepted: 11-12-2018 Published: 25-12-2018

\begin{abstract}
A central venous catheter is a catheter that is placed directly on a large vein in the body and its tip lies in one of the central veins that is often used on critical care patients. Colonization of bacteria (germ) around the insertion area of the CVC is an area that is very likely to cause infection even though it has been closed by dressing. The factor that should always be considered is that the state of moisture retention occurs beneath the dressing. Moisture will cause an increase in colonization of the insertion area and increase the risk of catheter-related infection. As is known the humidity level of Indonesia with other countries is higher and the results of positive swabs in the insertion area are associated with Percutaneous Central Venous Catheter (PCVC) colonization and Catheter-related Sepsis (CRS). Transparent polyurethane and plaster gauze are two types of dressings that are different and often used. The transparent polyurethane is widely used in invasive procedures, there are still many medical staff who use plaster gauze dressings. The purpose of this study is to determine the difference in the number of germs in the CVC insertion area that are dressed using transparent polyurethane and plaster gauze. The design of this study is a quasi-experimental pretest-posttest control group with positive sampling. The number of samples is 12 for the intervention group and 11 for the control group. The intervention group performed transparent polyurethane dressings and a control group with plaster gauze. Calculation in the number of germs is with the cup count method. Wilcoxon and Mann-Whitney tests are for te data analysis. Based on the results of the study, it can be concluded that there is no difference in the number of CVC insertion germs between the use of dressings transparent polyurethane and plaster gauze so that both types of dressings can be used for CVC dressings in critical patient care settings.
\end{abstract}

Keywords: CVC insertion area, dressing, number of germs, plaster gauze and transparent polyurethane. 
Septiana : Differences in The Number of Germs in The Insertion Area of Central Venous Catheter

\section{Introduction}

Patients in critical care units have a risk that threatens their lives. According to Urden et al. (2010), critical care patients are at high risk for life-threatening health problems both actual and potential. Hemodynamic monitoring of patients with critical conditions in the ward need to be used to detect cardiovascular insufficiency, differentiate contributing factors and instructions for therapy (Bersten \& Soni, 2009). Technology related to hemodynamic monitoring, one of which is monitoring Central Venous Pressure (CVP) (Woods et al., 2010). At the hospital research site in the city of Bandung, there are several treatment rooms for adult patients, where CVC patients often have to be treated.

For the large number of CVC installations in intensive care and high care settings, it is necessary to pay attention to the disadvantages of using central venous access (Doughherty, 2006). Infection is one of the complications of using CVC. Chateterrelated infection plays a role in the spread of causes of nosocomial infections based on the facts in critical care and is associated with an increase in Length of Hospital Stay (LOS) (Ramntu et al., 2008). The term used to describe catheter-related infection are two, namely Central Line Associated Blood Stream Infection (CLABSI) and Catheter Related Blood Stream Infection (CRBSI) (Kusek et al., 2012). According to Tarpatzi et al. (2012) the mortality rate of patients with CRBSI was $11.3 \%$.

The use of CVC is related to infection in blood flow caused by microorganisms that colonize the external surface of the CVC. The pathogenesis of the CVC CLABSI can become contaminated with two major routes, namely the generalum route and the intraluminal route. The extraluminal route is that the skin organisms of the patient in the insertion area can migrate along the surface of the catheter to the cutaneous catheter around the catheter and produce colonization at the catheter's end (O'Grady, 2011). Besides that the wound condition, in this case the insertion wound will also be affected by the level of albumin and food intake (Said et al., 2016).

To control infections due to $\mathrm{CVC}$ installation, health workers need to carry out strategies. According to the Centers for Disease Control and Prevention (CDC), National Nosocomial Infection Surveillance System (NNIS) in Woods et al. (2010), control can be done with a dressing. Dressings are used for wound care including CVC insertion wounds include Transparent dressing, Hydrocolloid, Hydrogel, Foam, Alginates, Gauze, Composites and Silver dressings (Baird \& Bethel, 2011). CVC dressings used in hospitals where research in Bandung is Transparent Polyuretane and gauze tape (gauze and tape).

The treatment of wound area with transparent polyurethane dressing and gauze has its own advantages. Wound care with a transparent polyurethane dressing has the advantage of being able to see the wound state, prevent moisture loss from wound, protect from external contamination, protect from friction, and can be used as a second dressing over other types of dressings. Whereas excess wound care with gauze is inexpensive (cheap), easy to use, ideal for wrapping wounds (Baird \& Bethel, 2011). However, based on research conducted by Webster et al. (2011) on CVC care, CRBSI is a higher in groups of transparent polyurethane when compared to gauze and tape; $\mathrm{OR}=4.19$ $(95 \% \mathrm{CI}=1.02$ to 17.23$)$

Based on the background above, the researcher wanted to examine the difference in the number of germs in the area of CVC insertion that was dressed using transparent polyurethane and plaster gauze.

\section{Method}

The research design used in this study is Quasi Experiment, a quasi-experimental design (Notoatmodjo, 2010). Quasi Experiment used in this study is nonequivalent control group pretest-posttest design (Polit \& Beck, 2004). The independent variable in this study was the intervention of CVC insertion area dressing with transparent polyurethane and CVC insertion area dressing with plaster gauze. The dependent variable in this study is the difference in the number of germs in the CVC insertion area.

The population in this study were patients who carried out CVC installation in several 
Septiana : Differences in The Number of Germs in The Insertion Area of Central Venous Catheter

rooms in hospitals where research in Bandung such as operating rooms, intensive rooms and high care rooms. While the sampling in this study is non-random (non-probability), that is sampling is not random, sampling is not based on the possibility that can be calculated. In this study the number of samples involved in accordance with the inclusion and exclusion criteria determined were 12 patients in the intervention group and 11 patients in the control group using purposive sampling technique (Arikunto, 2010). This is due to the limited number of beds in the intensive care unit so that the number of samples is limited and the research time is limited

Inclusion criteria in this study were 1) Patients who followed CVC insertion from the beginning; 2) Patients undergoing tunneled CVC installation; 3) Patients who carried out CVC insertion in subclavian veins; and 4) Patients who performed CVC with 3 lumens. Exclusion criteria in this study were patients with CVC wounds that were wet and multiple CVC. While the criteria for drop out in this study were patients who died before the post dressing smear was carried out or the patient refused to continue following the research process. In this study there were 4 respondents dropped out because the patient died before the 72 hour post dressing smear was carried out.

Data Analysis in this study uses univariate and bivariate analysis. Univariate analysis in this study was in the form of data on age, sex, length of day of hospital treatment prior to installation of CVC, CVC installer, CVC installation room and treated patient room. Categorical data including age, gender, CVC installation room and patient room are described with frequency and percentage. Numerical data includes the length of day of hospital treatment before the CVC installation is described with the mean. The data normality test used in this study is the Shapiro-Wilk test because the sample size in this study is 50 , with a significance value (p) $>0.05$ (Dahlan, 2012).

The comparative test used to determine the difference in the average number of germs before and after dressing in the intervention and control groups was the Wilcoxon test (nonparametric test) because the data on the number of germs before and after the dressing were not normally distributed with a value of $p<0.05$ ( $p=0.00$ and $p$ posttest $=0.00)$. The comparative test used to determine the difference in the mean (prepost difference) of the number of germs in the intervention group and the control group using the unpaired numerical comparative test with 2 groups, the Mann Whitney test (non-parametric test) because the data from both data were not distributed normal with $p$ $<0.05(\mathrm{p}=0.00$ and $\mathrm{p}=0.00)$.

\section{Result}

The results obtained from data processing and data analysis will be discussed in several parts, namely the characteristics of respondents, characteristics related to CVC installation in patients, description of the number of germs in the CVC insertion area in the control group and the intervention group, differences in the mean number of germs in the insertion area CVC before and after dressing in the control group and intervention group as well as differences in mean difference ("pre-test and post-test") number of CVC insertion area germs in the control group and intervention group.

Characteristics of respondents were seen from demographic data in the research observation sheet. Characteristics of respondents are shown in the table below:

Based on Table 1, it can be seen that the characteristics of age respondents are in the control group and the intervention group almost has the same characteristics. The highest gender in the control group was 6 women $(60 \%)$ and in the intervention group 8 men $(61.5 \%)$.

Based on Table 2 above shows that the average length of patient care before CVC installation was 5.167 days in the intervention group and 2.09 days in the control group. The most CVC installers in the intervention group were 11 residents $(73.3 \%)$ and 7 in the control group $(87.5 \%)$. The most CVC installation space in the intervention group was GICU 8 installation and in the control group was MIC 8 installation. The majority of patients in the intervention group were treated at GICU 8 and in the control group were treated in the MIC room. 
Septiana : Differences in The Number of Germs in The Insertion Area of Central Venous Catheter

Table 1 Frequency Distribution and Mean Characteristics of Respondents in The Control and Intervention Groups $(\mathbf{n}=\mathbf{2 3})$

\begin{tabular}{llcccc}
\hline \multirow{2}{*}{ Characteristics } & \multicolumn{4}{c}{ Group } \\
\cline { 3 - 6 } & & \multicolumn{2}{c}{ Intervention $(\mathbf{n}=\mathbf{1 2})$} & \multicolumn{2}{c}{ Control (n= 11) } \\
\cline { 2 - 5 } & Total & $\mathbf{\%}$ & Total & $\mathbf{\%}$ \\
\hline Age & Late Teenager (17-25 tahun) & 3 & 50 & 3 & 50 \\
& Early Adult (26-35 tahun) & 1 & 33.6 & 2 & 66.7 \\
& Late Adult (36-45 tahun) & 3 & 50 & 3 & 50 \\
& Early Elderly (46-55 tahun) & 2 & 50 & 2 & 50 \\
& Late Elderly (56-65 tahun) & 3 & 75 & 1 & 25 \\
\multirow{3}{*}{ Sex } & Male & 8 & 61.5 & 5 & 38.5 \\
& Female & 4 & 40 & 6 & 60 \\
\hline
\end{tabular}

Table 2 Frequency Distribution and Mean Characteristics Related to CVC Installation of Patients in The Control and Intervention Groups $(n=23)$

\begin{tabular}{|c|c|c|c|c|c|}
\hline & \multirow{3}{*}{ Characteristics } & \multicolumn{4}{|c|}{ Group } \\
\hline & & \multicolumn{2}{|c|}{ Intervention $(\mathrm{n}=12)$} & \multicolumn{2}{|c|}{ Control $(n=11)$} \\
\hline & & Total & $\%$ & Total & $\%$ \\
\hline $\begin{array}{l}\text { Treatment } \\
\text { duration }\end{array}$ & average & \multicolumn{2}{|c|}{5.167} & \multicolumn{2}{|c|}{2.09} \\
\hline \multirow{2}{*}{$\begin{array}{l}\text { CVC } \\
\text { Installation }\end{array}$} & Medical Specialist & 1 & 12.5 & 7 & 87.5 \\
\hline & Resident & 11 & 73.3 & 4 & 26.7 \\
\hline \multirow{4}{*}{$\begin{array}{l}\mathrm{CVC} \\
\text { Installation } \\
\text { room }\end{array}$} & Operation Room & 4 & 100 & 0 & 0 \\
\hline & $\begin{array}{l}\text { General Intensive Care Unit } \\
\text { (GICU) }\end{array}$ & 8 & 100 & 0 & 0 \\
\hline & $\begin{array}{l}\text { Moderate Intensive Care } \\
\text { (MIC) }\end{array}$ & 0 & 0 & 8 & 100 \\
\hline & Flamboyan Inpatient Room & 0 & 0 & 3 & 100 \\
\hline \multirow[t]{4}{*}{$\begin{array}{l}\text { Patient } \\
\text { Room }\end{array}$} & $\begin{array}{l}\text { General Intensive Care Unit } \\
(\text { GICU) }\end{array}$ & 8 & 100 & 0 & 0 \\
\hline & $\begin{array}{l}\text { Cardiac Intensive Care Unit } \\
\text { (CICU) }\end{array}$ & 4 & 100 & 0 & 0 \\
\hline & Moderate Intensive Care (MIC) & 0 & 0 & 8 & 100 \\
\hline & Flamboyan Inpatient Room & 0 & 0 & 3 & 100 \\
\hline
\end{tabular}

Table 3 Overview of The Number of Germs in The Control and Intervention Groups $(n=23)$

\begin{tabular}{lccc}
\hline \multicolumn{1}{c}{ Group } & Total Germ Average & & \\
\hline & Pre-test & Post-test & (Pre-test dan Post-test) \\
\hline Control & $9.25 \times 10^{5}$ & $6.03 \times 10^{7}$ & $5.9 \times 10^{7}$ \\
Intervention & $9.05 \times 10^{5}$ & $2.66 \times 10^{6}$ & $1.7 \times 10^{6}$ \\
\hline
\end{tabular}

The following is a description of the average number of germs in the CVC insertion area both in the control group and in the intervention group:
Table 3. Overview of The Number of Germs in The Control and Intervention Groups $(\mathrm{n}=23)$

Based on Table 3 above shows that the 
Septiana : Differences in The Number of Germs in The Insertion Area of Central Venous Catheter

Table 4 Statistical Tests of Differences in The Average Number of Germs Before and After Dressing in The Control Group and Intervention Group $(\mathbf{n}=\mathbf{2 3})$

\begin{tabular}{lcccc}
\hline \multicolumn{1}{c}{ Group } & \multicolumn{2}{c}{ Total Germs } & & \\
\hline & Pretest & Postest & $\mathbf{Z}$ & p \\
\hline Control & $9.25 \times 10^{5}$ & $6.03 \times 10^{7}$ & 0.533 & 0.594 \\
Intervention & $9.05 \times 10^{5}$ & $2.66 \times 10^{6}$ & 0.889 & 0.374 \\
\hline
\end{tabular}

Table 5 Statistical Test of Differences in Mean Difference ("Pre-Test and Post-Test") Number of CVC Insertion Germs in The Control Group and Intervention Group $(\mathbf{n}=\mathbf{2 3})$

\begin{tabular}{lcccc}
\hline \multicolumn{1}{c}{ Group } & \multicolumn{2}{c}{ Total Germs Difference } & $\mathbf{~}$ & $\mathbf{p}$ \\
& \multicolumn{2}{c}{ (Pre test dan Post test) Jumlah Kuman } & & \\
& Postest & & -0.369 & 0.712 \\
\hline Control & $5.9 \times 10^{7}$ & $1.9 \times 10^{8}$ & & \\
Intervention & $1.7 \times 10^{6}$ & $5.7 \times 10^{6}$ & & \\
\hline
\end{tabular}

number of bacteria increased by $5.9 \times 10^{7}$ colonies in the control group and $1.7 \mathrm{x}$ $10^{6}$ colonies in the intervention group. On average in both groups the number of germs increased, but in the intervention group the number of germs in the CVC insertion area increased less than in the control group.

Based on the normality test performed on the data the average number of pre-test and post-test germs in the intervention and control groups were $p=0.00(p<0.05)$, the data were not normally distributed. Bivariate statistical tests to examine differences in the average number of germs before and after dressing in the control group and intervention group were by Wilcoxon test. Statistical test results are shown in the table below.

Based on Table 4 above, the results of the statistical test of the difference in the number of germs before and after dressing in the control group was $p=0.594(p>0.05)$ thus $\mathrm{H}_{0}$ failed to be rejected. These results indicate that there is no significant difference in the number of germs before and after the dressing with plaster gauze. Statistical test results of differences in the number of germs before and after dressing in the intervention group were $\mathrm{p}=0.374(\mathrm{p}>0.05)$, thus $\mathrm{H}_{0}$ failed to be rejected. These results showed no significant difference in the number of germs before and after dressing with transparent polyurethane.

Based on the results of the normality test, data on the difference in the number of germs in the intervention group and also in the control group were not normally distributed with $\mathrm{p}=$ $0.00(p<0.05)$. Statistical calculations used to test differences in mean differences (pretest and posttest) of the number of germs in the control group and the intervention group were the Mann-Whitney test, as follows.

Referring to Table 5 above shows that $\mathrm{H}_{0}$ failed to be rejected because the value of $p>$ $0.05(\mathrm{p}=0.712)$, so it can be concluded that there is no difference in mean of the difference (repre test and post test) the number of CVC insertion area germs in the control group and group intervention.

\section{Discussion}

Characteristics of critical patient respondents in the control group and intervention group in this study had similar characteristics between the two groups. Patients in this study started from late adolescence to late elderly. The youngest age in this study was 17 years old and the oldest was 63 years. This is consistent with research in October 2000 to February 2002 at two university hospitals in Germany, where the sample in this study patients who carried out CVC installation ranged in age from 18-80 years (Yucel et al., 2004). Age aspects are factors that influence the incidence of infection due to CVC installation. In the study involving respondents who were not too young and too old (extreme). This is in line with Poderman and Girbes (2002) that extreme age both too young and too old is a risk factor for infection due to CVC installation.

The highest gender in the control group 
Septiana : Differences in The Number of Germs in The Insertion Area of Central Venous Catheter

was 6 women $(60 \%)$ and in the intervention group 8 men $(61.5 \%)$. This is consistent with research conducted by Ranucci et al. (2003) where almost the same frequency of both sexes in CVC insertion, of 355 patients included in this study were 174 male and 181 female patients. The sex of the patient is one of the risk factors for the incidence of infection due to CVC insertion (Kusek et al., 2012).

Based on Table 3 shows that the number of bacteria increased by $5.9 \times 10^{7}$ colonies in the control group and $1.7 \times 10^{6}$ colonies in the intervention group. The number of germs in the CVC insertion area of the intervention group increased less than in the control group.

The number of germs increases with the length of time that CVC is used. The number of germs in both groups can increase due to several things such as the virulence of the organism, the amount of inoculation, the place of entry of germs and host immunity. Length of catheter use is a common risk factor in CRBSI (Yoshida et al., 2011). In the study of Yucel et al. (2004) S. Aureus was even identified on the skin surface of patients using CVC. This needs to be considered because according to O'Grady et al. (2011), CVC can be contaminated with an extraluminal pathway. This is what can later cause infection if it is not managed properly.

In the intervention group, germs were added to the CVC insertion area, which was done with less transparent polyurethane dressing than the plaster gauze. It occurs because the dressings with transparent cover well the CVC insertion area when attached. Besides that transparent polyurethane is semipermeable which can prevent bacterial, viral, other foreign matter contamination and water resistant while maintaining skin breathing, so as to maintain skin integrity. This reinforces that dressing with transparent polyurethane has the advantage of protecting it from external contamination (Baird \& Bethel, 2011). Based on the important criteria (SSIVD), it states that the use of transparent dressing is the right choice of dressing to minimize the risk of infection (Kergon \& Obasi, 2010).

Based on Table 4, the difference in the number of germs before and after dressing in the control group was $p=0.594(p>0.05)$, so there was no significant difference in the number of germs before and after the dressing with a plaster gauze. This is because dressings are carried out every day in accordance with the Standard Operating Procedure (SOP) with normal saline fluid. Normal saline fluid is effective enough to clean around the CVC insertion area. Simcock (2001) recommends cleaning the outer area of insertion with normal saline and sterile gauze with the aim of removing blood, exudates or impurities that make the possibility of infecting. This is in line with Rickard et al. (2004) who included the use of sterile gauze dressings to close the insertion of CVC catheters at the level of evidence IA, which is strongly recommended. Thus strengthening the results of this study that stressed with plaster gauze with $\mathrm{NaCl} 0$ cleaning fluid, $9 \%$ is effective enough to protect against germ contamination by treatment according to SOP.

The difference in the number of germs before and after dressing in the intervention group was $p=0.374(p>0.05)$. There was no significant difference in the number of germs before and after the dressing with transparent polyurethane. As described above, the dressings with transparent cover well the CVC insertion area when attached. Besides that transparent polyurethane is semipermeable which can prevent bacterial, viral, other foreign matter contamination and water resistant while maintaining skin breathing, so as to maintain skin integrity. Therefore, the difference in the number of germs in the CVC insertion area before and after the dressing with transparent polyurethane is not significant. This reinforces that dressing with transparent polyurethane has the advantage of protecting it from external contamination (Baird \& Bethel, 2011).

The research that is in agreement with this research is a research with a meta-analysis conducted by Maki and Marmel (1997) which compares seven studies of high-risk dressings. The results of this meta-analysis are pooler risk of infection 2.7 per $100 \mathrm{CVC}$ installations with sterile gauze and 2.5 per 100 CVC installations with semipermeable transparent adhesive polyurethane (PU). Weight relative risk is 1.06 (95 CI, 0.59 to $1.90, p=0.85)$. Based on the above research, it is a strong aspect that PU dressings which 
Septiana : Differences in The Number of Germs in The Insertion Area of Central Venous Catheter

are used in high risk populations, non cuffed CVC used for temporarily access and they do not increase the risk of CVC associated with blood stream infection (Maki \& Mermel, 1997). Ther were another research, namely prospective, randomized trial of 100 (59 women and 41 men) critical patients with liver problems in the ITU Liver, Qoeen Elizabeth Hospital Birmingham. Microbial analysis at entry site wound, the entry site, and CVC tip was carried out in 75 patients. 36 patients with Tegaderm dressing and 39 with IV3000. There were no significant differences in the incidence of contamination $(p>0.1)$. The number of microorganisms isolated from the skin under two types of dressings is not significantly different. In the Opsite IV3000 dressings the number of organisms present is $3.2 \times 10^{4} ; 5.2 \times 10^{4}$; and in Tegaderm dressings $4.1 \times 10^{4} ; 8.6 \times 10^{4}$. Swab culture in insertion area wounds, there was no significant difference between the two types of dressings transparent for the number of isolated organisms in the wound area ( $p$ $>0.1$ ) (Renolds et al., 1997). Thus it is clear that dressings with transparent polyurethane according to SOP are effective enough to protect against germ contamination.

Referring to Table 5 shows that there is no difference in mean of differences in differences ("pre-test and post-test") the number of CVC insertion area germs in the intervention group and the control group $(\mathrm{p}$ $=0.712$ ). There is no significant difference made possible because in the study between the two groups for the characteristics of age and sex are almost the same. Age and gender are two of several risk factors for infection due to CVC installation (Poderman \& Girbes, 2002). In this study controlled the incidence of infection due to CVC installation using a good skin antiseptic using 70\% alcohol and povidone iodine in both groups. According to Widani and Nasution (2015), in other cases, oral care had a significant decrease in the number of bacterial colonies before and after oral care with providone iodine $(1 \%)$. In addition, it also applies appropriate insertion techniques according to hospital SOPs in this study. Hand hygiene is also always done before doctors who do the CVC installation start the action. All patients in this study also carried out CVC placement on a uniform venous location, the subclavian vein. According to the CDC (Centers for Disease Control and Prevention); NNIS (National Nosocomial Infection Surveillanc System) in Woods et al. (2010), infection control because the installation of CVC can indeed be done in stages (1) using the right skin antiseptic, (2) proper insertion techniques, (3) appropriate hand hygiene, (4) selection of the location of the correct insertion area, (5) using the right antimicrobial catheter, (6) replacing the catheter according to the indication, (7) dressing, (8) giving the right set of flush fluid and (9) doing Central venous culture and arterial catheters as needed.

In this study, when the CVC was installed, the proper insertion technique was used according to the hospital SOP, i.e. sterile barrier precaution technique. This was also done in the study of Yucel et al. (2004) which included the use of masks, hats, sterile dresses, gloves and duk. Area insertion is carried out by smear or cleaning with Alcohol $75 \%$. In this study also used povidone iodine to clean the stabbing area before the CVC was installed.

All patients in this study carried out CVC placement in the subclavian vein. According to Urden et al. (2006), in anticipation of CVC being installed for more than 5 days, installation of subclavian veins is better used for CVC installation. The incidence of infection in this subclavian vein position was lower and the patient's discomfort when using CVC in the lower subclavian vein position. CVC insertion in subclavia is associated with a lower risk of potential infection (Yucel et al., 2004).

Another thing that also affects the difference in the average difference in the number of germs in both groups is the length of day of treatment prior to installation of $\mathrm{CVC}$, where in both groups the average days of treatment before CVC installation was almost the same even though in the control group The average length of treatment before CVC installation is shorter which is 2.09 days. According to Poderman and Girbes (2002), prolonged hospitalization before $\mathrm{CVC}$ insertion is one of the risk factors for the incidence of infection due to CVC installation. According to Poderman and Girbes (2002), the underlying disease or condition is one of 
Septiana : Differences in The Number of Germs in The Insertion Area of Central Venous Catheter

the risk factors for the incidence of infection due to CVC installation.

The results of this study are in line with the Rondomized Controlled Trial (RCT) design study conducted by Barros et al. (2009) with a study subject of 66 hemodialysis patients at Sao Paulo Dialysis Unitat Hospital in September 2007-June 2008 which was divided into two groups, the control group and intervention groups (33 subjects per group). The control group was given a dressing in the CVC insertion area with gauze and micropore and the intervention group used transparent film dressing. The result is that there is no significant difference in the use of both types of dressings. Nonetheless, the use of transparent films based on qualitative data analysis shows that this type of dressing is preferred by patients and health care providers from university hospitals where the research was conducted.

Both types of CVC dressings both transparent polyurethane and plaster gauze can be used in critical care settings. In a study conducted by Rickard et al. (2004) in 14 hospitals in Australia, CVC dressings using semi-permeable transparent dominant were used. According to Rickard et al. (2004), the use of sterile, transparent, semi-permeable gauze dressing to cover CVC catheters at the level of evidence IA which means is highly recommended to be implemented and strongly supported by experimental, clinical design studies. or epidemiological studies. Patients who are intolerant of transparent dressing using sterile gauze and plaster for dressing. Dressing with gauze is better than transparent dressings if the patient is sweating, or if the condition is bleeding (Pratt et al., 2007).

Based on this study there is no significant difference in the mean difference of the number of germs in the insertion area between those using transparent polyurethane or those using plaster gauze with daily dressing using saline normal liquid. Therefore, the type of dressing selection not only based on the consideration of the type of dressing that can minimize the risk of infection but must also take into account other factors in the selection of dressings, namely whether it provides comfort for the patient (Kergon \& Obasi, 2010), safe protecting the catheter, easy to use and opened (Mallett \& Bailey, 1996). Research Limitation, This study still involved respondents with a minimum number of as many as 12 patients in the intervention group and 11 patients in the control group, of course this was a limitation in this study. With a larger number of respondents, the evidence will be able to show more differences between the two types of dressings, especially in terms of differences in the number of germs in the CVC insertion area that are dressed using Transparent Polyurethane and gauze tape (gauze and tape).

\section{Conclusion}

Based on the results of the research and description in the discussion, it can be concluded that there is no significant difference in the number of germs in the CVC insertion area of critical patients dressed using transparent polyurethane and using a plaster gauze. This shows that both types of dressings are appropriate for preventing external contamination of the CVC insertion area.

Suggestions in this study for further research is that research needs to be done with a larger number of samples so that the evidence is stronger and the difference in the number of germs from both types of dressings can further be seen.

\section{References}

Arikunto, S. (2010). Prosedur penelitian suatu pendekatan praktik. Jakarta: PT Rineka Cipta.

Baird, M.S., \& Bethel, S. (2011). Manual of critical care nursing: Nursing interventions and collaborative management. St Louis Missouri: Elsevier Mosby.

Barros, L.D.F.N.M., Arênas, V.G., Bettencourt, A.R.D.C., Diccini, S., Fram, D. S., Belasco, A.G.S., \& Barbosa, D.A. (2009). Evaluation of tow types of dressings used on central venous catheters for hemodialysis. Acta Paulista de Enfermagem, 22(SPE1), 
Septiana : Differences in The Number of Germs in The Insertion Area of Central Venous Catheter

481-486. http://dx.doi.org/10.1590/S010321002009000800004.

Bersten, A.D., \& Soni, N. (2009). Oh's intensive care manual. China: Elsevier.

Dahlan, M.S. (2012). Statistik untuk kedokteran \& kesehatan deskriptif, bivariat \& multivariat dilengkapi aplikasi dengan menggunakan SPSS.

Dougherty, L. (2006). Central venous access devices: care and management. Blackwell.

Kergon, E., \& Obasi C. (2010). Guidelines for the management of central venous catheters in adults. Bradford and Airedale Community Health Services.

Kusek, L., Soule, B.M., Kupka, H., \& Williams, S. (2012). Preventing central lineassociated bloodstream infection: A global challenge, a global perspective. USA: Joint Commission Publication.

Maki, D.G., \& Mermel, L. (1997). Transparent polyurethane dressings do not increase the risk of CVC-related BSI: A meta-analysis of prospective randomized trials. Soc Healthcare Epidemiol Am, 18(51).

Mallett, J., \& Bailey, C. (1996). The royal marsden NHS trust manual of clinical procedures. Blackwell Science: London.

Notoatmodjo, S. (2010). Metode penelitian kesehatan edisi revisi 2010. Rineka Cipta, Jakarta.

O'Grady, N.P. (2011). Healthcare infection control practices advisory committee. Guidelines for the prevention of intravascular catheter-rela-ted infections. Am $J$ Infect Control, 39, S1-34. https://doi.org/10.1093/ $\mathrm{cid} / \operatorname{cir} 257$.

Polderman, K.H., \& Girbes, A.R. (2002). Central venous catheter use. Intensive care medicine, 28(1), 1-17.https://doi. org/10.1007/s00134-001-1154-9.

Polit, D.F., \& Beck, C.T. (2004). Nursing research: Principles and methods. Lippincott Williams \& Wilkins.

Pratt, R.J., Pellowe, C.M., Wilson, J.A., Loveday, H.P., Harper, P.J., Jones, S.R.L.J., ... \& Wilcox, M.H. (2007). National evidencebased guidelines for preventing healthcareassociated infections in NHS hospitals in England. Journal of Hospital infection, 65, S1-S59. $\quad$ https://doi.org/10.1016/S01956701(07) 60002-4.

Ramritu, P., Halton, K., Cook, D., Whitby, M., \& Graves, N. (2008). Catheter-related bloodstream infections in intensive care units: A systematic review with metaanalysis. Journal of advanced nursing, 62(1), 3-21. https://doi.org/10.1111/j.13652648.2007.04564.x.

Reynolds, M.G., Tebbs, S.E., \& Elliott, T.S. (1997). Do dressings with increased permeability reduce the incidence of central venous catheter related sepsis?. Intensive and Critical Care Nursing, 13(1), 26-29. https:// doi.org/10.1016/S0964-3397(97)80688-X.

Rickard, C.M., Courtney, M., \& Webster, J. (2004). Central venous catheters: A survey of ICU practices. Journal of advanced nursing, 48(3), 247-256. https://doi.org/10.1111/ j.1365-2648.2004.03193.x.

Said, S., Taslim, N.A., \& Bahar, B. (2016). Hubungan IMT dan kadar albumin berhubungan dengan penyembuhan luka. Jurnal Keperawatan Padjadjaran, 4(1). https://doi.org/10.24198/jkp.v4i1.137.

Simcock, L. (2001). Complications of CVCs and their nursing management. Nursing times, 97(20), 36-38.

Tarpatzi, A., Avlamis, A., Papaparaskevas, J., Daikos, G.L., Stefanou, I., Katsandri, A., ... \& Petrikkos, G. L. (2012). Incidence and risk factors for central vascular catheter-related bloodstream infections in a tertiary care hospital. Microbiologica-Quarterly Journal of Microbiological Sciences, 35(4), 429.

Urden, L.D., Stacy, K.M., Thelan, L.A., \& 
Septiana : Differences in The Number of Germs in The Insertion Area of Central Venous Catheter

Lough, M.E. (2006). Thelan's critical care nursing: Diagnosis and management. Mosby Inc.

Urden, L.D., Stacy, K.M., Lough, M.E. (2010). Critical care nursing diagnosis and management. St. Louis Missouri: Volve Learning System Mosby. Elsevier.

Webster., J, Gillies, D., O’Riordan, E., Sherriff, K.L., \& Rickard, C.M. (2011). Gauze and tape and transparent polyurethane dressings for central venous catheters (Review). The Cochrane Collaboration. Published by JohnWiley \& Sons, Ltd: 1-37.

Widani, N.L., \& Nasution, Y. (2015). Perbandingan oral care menggunakan povidone iodine $1 \%$ dengan chlorhexidine $0.2 \%$ terhadap jumlah bakteri di mulut pada pasien penurunan kesadaran. Jurnal Keperawatan Padjadjaran, 3(3). https://doi. org/10.24198/jkp.v3i3.120.
Woods, S.L., Froelicher, E.S.S., Motzer, S.U., $\&$ Bridges, E.J. (2010). Cardiac nursing ( $6^{\text {th }}$ Ed.). Philadelphia: Wolters Kluwer Health Lipincott Williams and Wilkins.

Yoshida, J., Ishimaru, T., Kikuchi, T., Matsubara, N., \& Asano, I. (2011). Association between risk of bloodstream infection and duration of use of totally implantable access ports and central lines: a 24-month study. American journal of infection control, 39(7), e39-e43. https: //doi. org/10.1016/ j.ajic.2010.11.013.

Yücel, N., Lefering, R., Maegele, M., Max, M., Rossaint, R., Koch, A., ... \& Schierholz, J. (2004). Reduced colonization and infection with miconazole-rifampicin modified central venous catheters: A randomized controlled clinical trial. Journal of antimicrobial chemotherapy, 54(6), 1109-1115. https://doi. org/10.1093/jac/dkh483. 